\title{
Fish scavenging behaviour in recently trawled areas
}

\author{
M. J. Kaiser, B. E. Spencer \\ Ministry of Agriculture, Fisheries and Food, Directorate of Fisheries Research, Fisheries Laboratory, Benarth Road, Conwy, \\ Gwynedd LL32 8UB, United Kingdom
}

\begin{abstract}
The diets of gurnards Aspitrigla cuculus and Eutrigla gurnardus, lesser-spotted dogfish Scyliorhinus canicula and whiting Merlangius merlangus were examined to determine whether they migrated into recently trawled areas to feed on animals that may be damaged or dislodged by the action of a $4 \mathrm{~m}$ beam trawl. Gurnards and whiting increased their intake of prey after an area had been fished. In particular, they increased the proportion of the amphipod Ampelisca spinipes in their diets. Beam trawling damaged the purple burrowing heart urchin Spatangus purpureus, scallop Aequipecten opercularis, Ensis spp. and Laevocardium sp., exposing internal tissues which were then eaten by whiting. Some mobile invertebrate scavengers, such as Pandalus spp., only occurred in diets after the area had been fished, suggesting that these animals were also scavenging over the trawl tracks. Observations of the seabed using a side-scan sonar revealed a greater concentration of fish marks around the trawl tracks than in adjacent unfished areas. Our results indicate that fish rapidly migrate into beam trawled areas to feed on benthic animals which have been either damaged or disturbed by fishing or on scavenging invertebrates. In areas where certain benthic communities occur, beam trawling intensity may be such that it creates a significant food resource for opportunistic fish species. This is a possible mechanism whereby long-term community structure could be altered by fishing activity.
\end{abstract}

KEY WORDS: Beam trawling $\cdot$ Scavengers $\cdot$ Disturbance $\cdot$ Community structure $\cdot$ Diet change

\section{INTRODUCTION}

Recent research indicates that a variety of fishing gears such as beam trawls (Bergman \& Hup 1992), otter trawls (Van Dolah et al. 1987, 1991, Rumohr \& Krost 1991) and dredges (van der Veer et al. 1985, Eleftheriou \& Robertson 1992) cause increased local mortalities of some epi- and infaunal benthic organisms. Consequently, this may lead to increased opportunistic feeding by invertebrate (Wassenberg \& Hill 1987) and fish predators (present study). Repeated fishing in areas such as the North Sea (Rijnsdorp et al. 1991) has been cited as one possible cause of observed long-term changes in benthic community structure (Pearson et al. 1985, Berghahn 1990, Lindeboom 1990. Hall 1994). In the Irish Sea, otter and beam trawling are the main fishing methods used to catch demersal fish (McCandless 1992). Although otter trawling is more common than beam trawling (McCandless 1992), because of their design and method of deployment, beam trawls have greater potential to affect the seabed and benthic communities. Typically, they are fished with chain matrices (Arkley 1991) which are designed to disturb flatfish, in particular sole Solea solea, that remain buried in the sediment during the day. Early studies demonstrated that tickler chains penetrate down to a total depth of $3 \mathrm{~cm}$ in firm sand (Bridger 1970,1972 ) and up to $8 \mathrm{~cm}$ in softer ground (BEON 1991). An unavoidable side-effect of this digging action is that the gear removes and/or damages fragile infauna, for example burrowing heart urchins, Echinocardium cordatum and the quahog Arctica islandica (Bergman \& Hup 1992), and also increases the epifaunal by-catch (Creutzberg et al. 1987, Kaiser et al. 1994). The consequences of these short-term effects on changes in faunal abundance and mortality have been the main subject of recent studies (BEON 1991, Bergman \& Hup 1992).

While it is important to understand the direct effects of fishing on marine communities, the indirect effects are equally pertinent and may be most obviously manifested in populations of predators higher on the food chain which exploit prey that are killed, damaged or discarded by fishermen (Furness \& Hislop 1981 , 
Furness 1982, Wassenberg \& Hill 1987). For example, the observed population explosion of some species of marine birds has been linked to the increase of discards from fisheries in the North Sea (Furness 1982). To date, few studies have examined the implications of fishing activities for non-avian scavengers (but see Wassenberg \& Hill 1987), and most of the available data is either circumstantial or unpublished. For example, dabs Limanda limanda, have been filmed feeding on trawl tracks in the North Sea several hours after fishing occurred (G. Rauck, samples on video; M. Fonds pers. comm.) and it is common practice for fishermen to re-fish recently trawled areas to exploit these aggregations of fish.

As part of a wider programme to examine some aspects of the short- and long-term effects of beam trawling on a benthic community in the Irish Sea, we have investigated the diets of gurnards Aspitrigla cuculus and Eutrigla gurnardus, lesser-spotted dogfish Scyliorhinus canicula and whiting Merlangius merlangus. The aim of this study was to determine whether these fish move into recently trawled areas to feed on animals either killed or dug up by the passage of a beam trawl or on other immigrating scavengers.

\section{GENERAL METHODS}

Beam trawling was carried out by the RV 'Corystes' off the east coast of Anglesey, North Wales, in August 1992, April 1993 and April 1994. The experimental protocol and locations differed on each occasion as other experiments were incorporated into the research programme, hence, we have treated each date as a different experiment.

On each occasion, a wayline was plotted on the ships plotter, and fished using the same $4 \mathrm{~m}$ commercial pattern beam trawl fitted with chain matrix (Fig. 1) and a net fitted with an $80 \mathrm{~mm}$ diamond mesh codend. Warp length was set at 3 times the water depth. Towing speed was approximately 4 knots (ca $2.0 \mathrm{~m} \mathrm{~s}^{-1}$ ).

The ship's position was given by a Sercel NR53 Differential Global Positioning System (DGPS) navigation system, with an average accuracy of $\pm 2.5 \mathrm{~m}$, and relayed to the navigation plotter. In addition, a navigational software package (Sextant) displayed the ship and beam trawl's position relative to the plotted wayline. The beam trawl's position, relative to the ship, was determined using a transponder fitted to the centre of the beam. This allowed us to determine the proximity of repeated trawls to an accuracy of $\pm 2.5 \mathrm{~m}$. The trawl was fished in the same direction as the tidal current to minimise the offset of the trawl track from the ship's plotted track. The ship's position was also

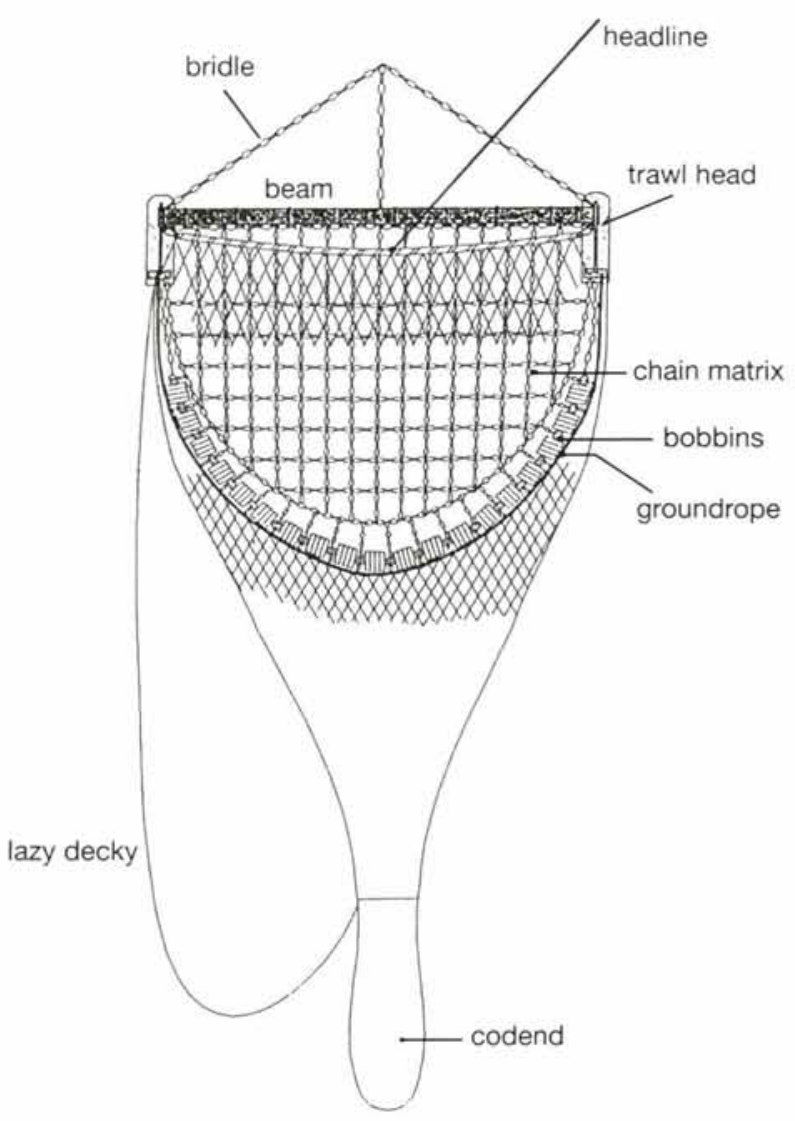

Fig. 1. A commercial pattern $4 \mathrm{~m}$ beam trawl with the net removed to show the chain matrix. Beam length $=4 \mathrm{~m}$, headline length $=3.7 \mathrm{~m}$, groundrope $=9.4 \mathrm{~m}$, chain link diameter $=18 \mathrm{~mm}$, total weight of gear out of water $=2340 \mathrm{~kg}$. Diagram by $\mathrm{H}$. Polet

recorded every $1 \mathrm{~s}$ using Microplot software which displayed a plot of the ship's tracks. Sediment type was characterised using echo-sounder readings analysed by 'RoxAnn', a seabed discrimination system, and confirmed by visual examination of 5 Day grab samples collected at each site. This indicated that the sediments at each site were composed of coarse sand, gravel and broken shell.

On each occasion the experimental protocol followed a similar pattern. Initially either 3 or 4 repeated tows were made along the same plotted wayline. This had 2 functions: (1) to create a disturbance effect using a commercial $4 \mathrm{~m}$ beam trawl and (2) to collect fish which presumably had not been feeding on trawled areas. It was necessary to use at least 3 tows to collect enough fish for stomach contents analysis. After a period of $2 \mathrm{~h}$, the same wayline was repeatedly fished either 3 or 4 times to collect fish which may been feeding on the trawled area. All fishing was carried out between 09:00 and 18:00 h GMT in daylight (April: dawn 05:17 h, dusk 19:09 h; August: dawn 05:26 h, dusk 19:54 h GMT). 
Expt 1: August 1992. A wayline was fished off Dulas Bay, Anglesey (start of line $53^{\circ} 24.223^{\prime} \mathrm{N}, 04^{\circ} 08.419^{\prime} \mathrm{W}$; end of line $53^{\circ} 26.359^{\prime} \mathrm{N}, 04^{\circ} 08.678^{\prime} \mathrm{W}$ ). Tow duration for the first line was $30 \mathrm{~min}$. The second and third lines had tow durations of 20 and 10 min respectively, such that the centre of the first line was fished 3 times. The wayline was trawled 3 more times after an interval of $3 \mathrm{~h}$ such that the fourth, fifth and sixth tows had durations of 10,20 and $30 \mathrm{~min}$ respectively. We used tows of different duration to examine the effects of time spent in the codend on the suvival of captured animals, a study which will be reported elsewhere. However, as we used the same protocol to collect our fish before and after fishing, the effects of tow duration should not affect our results. Thirty dogfish and 30 gurnard were collected from hauls 1 to 3 , and from hauls 4 to 6 .

Stomach contents analysis: To investigate whether the fish were feeding in the trawled areas, each of the fish collected had its entire stomach preserved in $4 \%$ buffered formalin for later identification of contents to the lowest possible taxonomic level. Stomach fullness was scored using a scale of 0 (empty) to 10 (full). The contents of each stomach were weighed wet $( \pm 0.01 \mathrm{~g})$ after blotting on absorbent paper.

Morphometrics: Total length (to the nearest $\mathrm{cm}$ ) and maximum mouth gape $( \pm 0.1 \mathrm{~cm}$, across the articulation of the jaws of dogfish and between the upper and lower jaws of gurnards) of each fish were measured using a measuring board and vernier callipers respectively. The widest cross-sectional dimension of each prey item collected from stomach contents was measured using an eyepiece graticule and binocular microscope.

Expt 2: April 1993. A wayline was fished several miles to the south (start of line $53^{\circ} 22.122^{\prime} \mathrm{N}$, $04^{\circ} 08.870^{\prime} \mathrm{W}_{\text {; }}$ end of line $53^{\circ} 21.473^{\prime} \mathrm{N}, 04^{\circ} 07.066^{\prime} \mathrm{W}$ ) of that fished in August 1992. The wayline was fished a total of 6 times with an interval of $3 \mathrm{~h}$ between the first 3 and last 3 tows. Each beam trawl tow lasted $30 \mathrm{~min}$. On this occasion 40 specimens of whiting were collected from both the first and last 3 tows. Stomach contents and morphometrics were analysed as for gurnards in August 1992.

Side-scan sonar observations: After tows 3 and 6, the trawled area was surveyed with an EG\&G 260 dual frequency side-scan sonar system, linked to a side-scan sonar fish, model 262 , to check the spread of the trawled area. Records of fish shoals on the sonar trace were enumerated at intervals of $2 \mathrm{~min}$, noting whether they occurred over the fished or unfished areas. During this interval of time an area of ca $252 \times 200 \mathrm{~m}$ of the seabed was surveyed with the side-scan sonar towed at ca $2.0 \mathrm{~m}$ $\mathrm{s}^{-1}$, scanning a track of $100 \mathrm{~m}$ to starboard and port. The perpendicular distance of each fish mark from the centre of the trawl tracks was measured to determine the distribution of fish marks in the proximity of the tracks ( $\pm 1 \mathrm{~mm}$, i.e. approximately $1 \mathrm{~m}$ of seabed).

Expt 3: April 1994. A wayline was fished to the east of the previous sites (start of line $53^{\circ} 27.281^{\prime} \mathrm{N}$, $04^{\circ} 02.125^{\prime} \mathrm{W}$; end of line $53^{\circ} 25.992^{\prime} \mathrm{N}, 04^{\circ} 01.990^{\prime} \mathrm{W}$ ). The wayline was fished a total of 8 times with an interval of $2 \mathrm{~h}$ between the first and last 4 tows. Whiting were collected from the entire catch of each tow. The total length of each fish was measured and its stomach contents identified on board ship. No measurements of prey dimensions or mouth width were taken on this occasion.

\section{RESULTS}

\section{Expt 1: August 1992}

Dietary changes

The total number of prey items eaten by gurnards significantly increased after beam trawling, but dogfish did not increase their intake (Fig. 2) (gurnards, $\chi^{2}=19.2, \mathrm{p}<0.001$; dogfish, $\chi^{2}=2.09, \mathrm{p}>0.05$ ). Consequently, gurnards' stomach contents weight and fullness increased significantly, but no increase was observed in dogfish (Table 1). Gurnards significantly increased their intake of Liocarcinus depurator $\left(\chi^{2}=3.9\right.$, $\mathrm{p}<0.05)$, Crangon spp. $\left(\chi^{2}=9.7, \mathrm{p}<0.005\right)$ and Ampelisca spinipes $\left(\chi^{2}=29.5, \mathrm{p}<0.001\right)$ (Fig. 2$)$. There was no significant difference, before or after fishing, in the numbers of individual prey species eaten by dogfish. However, Pandalus spp. and Crangon spp. only occurred in dogfish stomachs after the area had been trawled.

\section{Morphometrics}

The ratio of total fish length: mouth gape width was not significantly different for either species of gurnard (mean $\pm \mathrm{SE}$ : Aspitrigla cuculus, $14.4 \pm 0.2$; Eutrigla gurnardus, $14.4 \pm 0.3$; ANOVA, $F_{1,58}=0.02, \mathrm{p}>0.90$ ), nor was there a significant difference between the relationship of prey width on gape width (ANCOVA, $F_{1.125}=2.45, \mathrm{p}>0.10$ ), hence the data for both species of gurnard were pooled. Within species, the mean lengths $(\mathrm{cm})$ of the gurnards and dogfish collected both before and after fishing were not significantly different (Table 2). The mean size of prey eaten by either gurnards or dogfish did not vary significantly either before or after fishing (Table 3). After fishing, the calculated prey width: gape width (pw:gw) ratio (estimated from the mean prey width eaten and the mean gape width) decreased for gurnards (before 0.23 , after 0.16 ) but remained similar for dogfish (before 0.19 , after 0.17 ). 

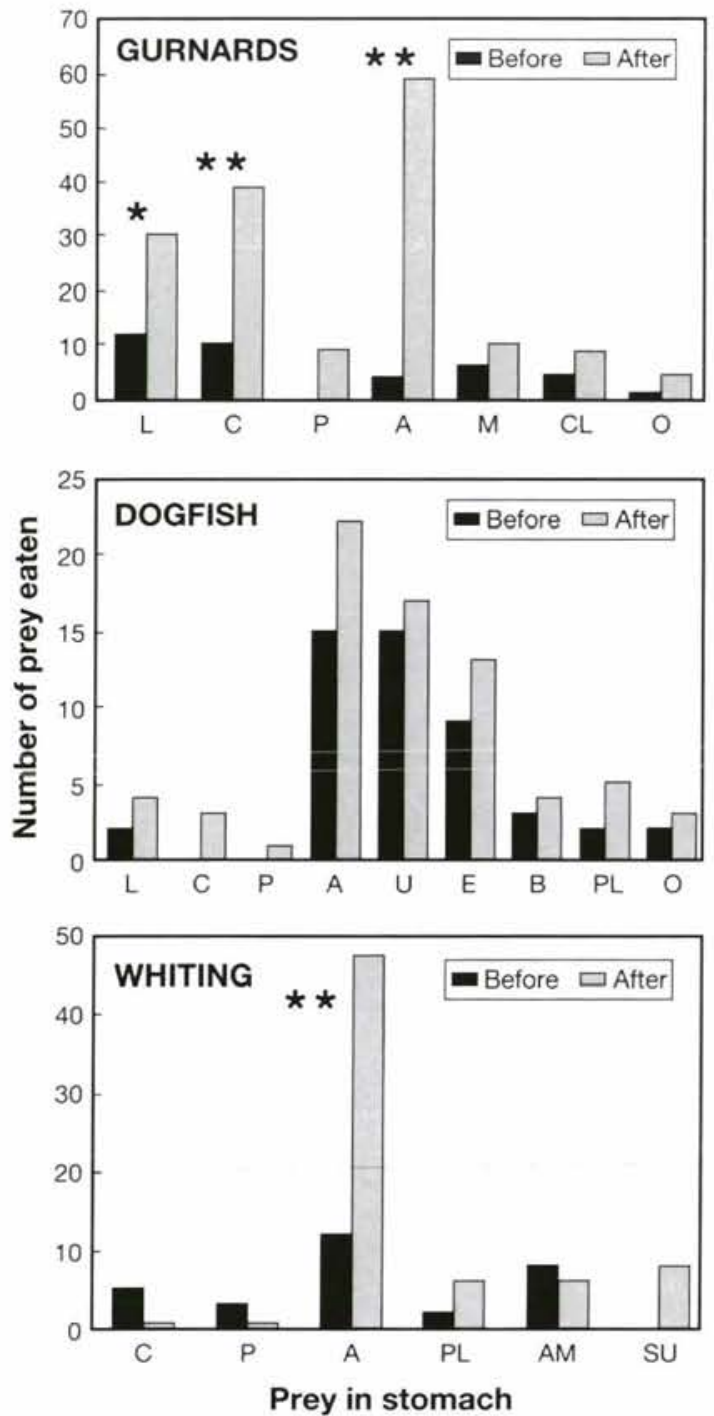

Fig. 2. Mean number of prey eaten by gurnards $(n=60)$, dogfish $(\mathrm{n}=60)$ and whiting $(\mathrm{n}=80)$ (whiting caught in 1993) which were collected both before and $3 \mathrm{~h}$ after fishing an area with a $4 \mathrm{~m}$ beam trawl. Significant differences were determined using $\chi^{2}, \cdot p<0.05, \cdots p<0.01$. Key to prey: L, Liocarcinus depurator; C, Crangon spp.; P, Pandalus spp.; A, Ampelisca spinipes; M, Macropodia spp.; CL, Callionymus spp.; U, Upogebia deltaura; E, Eupagurus bernhardus; B, Buccinum undatum; PL, polychaetes; AM, Ammodytes spp.; $\mathrm{SU}$, sea urchin gonads; $\mathrm{O}$, others

\section{Expt 2: April 1993}

\section{Dietary changes}

The total number of prey eaten by whiting increased significantly after trawling (Fig. $2, \chi^{2}=5.7, p<0.025$ ). After the area had been trawled, whiting significantly increased their intake of Ampelisca spinipes $\left(\chi^{2}=11.7\right.$. $p<0.005)$ and their stomachs contained the gonads
Table 1. Mean $\pm \mathrm{SE}$ stomach contents wet weight $(\mathrm{g})$ and fullness (scale of 0 to 10, empty to full) for gurnards Aspitrigla cuculus and Eutrigla gurnardus and dogfish Scyliorhinus canicula collected before and after intensive beam trawling $(\mathrm{n}=60)$. Comparisons are made using the Kruskal-Wallis non-parametric ANOVA $(H)$

\begin{tabular}{|c|c|c|c|c|}
\hline \multirow{2}{*}{ Species } & \multicolumn{2}{|c|}{ Stomach contents } & \multirow{2}{*}{$H$} & \multirow[t]{2}{*}{$\mathrm{p}$} \\
\hline & Before & After & & \\
\hline \multicolumn{5}{|c|}{ Contents weight } \\
\hline Gurnards & $0.98 \pm 2.57$ & $1.10 \pm 1.20$ & 8.47 & 0.004 \\
\hline Dogfish & $7.67 \pm 9.15$ & $4.06 \pm 4.56$ & 3.05 & 0.08 \\
\hline \multicolumn{5}{|l|}{ Fullness } \\
\hline Gurnards & $3.36 \pm 3.65$ & $5.04 \pm 3.23$ & 6.83 & 0.009 \\
\hline Dogfish & $4.23 \pm 2.80$ & $4.63 \pm 3.21$ & 0.18 & 0.67 \\
\hline
\end{tabular}

of the purple heart urchin Spatangus purpureus, which were not found in the stomachs of fish collected from the first series of 3 tows.

\section{Morphometrics}

The mean size of whiting examined before and after fishing did not vary significantly (Table 2 ). Whiting ate smaller prey after the wayline had been fished (Table 3). Consequently the pw: gw ratio decreased from 0.24 before fishing to 0.16 after fishing.

\section{Side-scan sonar observations}

A total length of $4300 \mathrm{~m}$ of the seabed was surveyed with the side-scan sonar after tow 3 and $4550 \mathrm{~m}$ after tow 6. Immediately after tow $3(15: 24$ to $16: 00 \mathrm{~h})$, 11 fish marks were observed over the fished area but only 1 was observed on the unfished area (Table 4 ) ( $t$-test, $t=2.2, \mathrm{df}=19, \mathrm{p}<0.04)$. However, immediately after tow $6(18: 26$ to $19: 00 \mathrm{~h})$ the number of marks observed over both the fished and unfished areas had increased by factors of 30 and 11 respectively (Table 4). Again there were significantly more fish marks (Fig. 3) over the fished as opposed to the unfished area ( $t$-test,

Table 2. Size range (mean $\pm \mathrm{SE}$ ) of gurnards Aspitrigla cuculus and Eutrigla gurnardus, dogfish Scyliorhinus canicula and whiting Merlangius merlangus collected before and after fishing. Comparisons were made using 1 -way ANOVA

\begin{tabular}{|c|c|c|c|c|c|}
\hline \multirow[t]{2}{*}{ Species } & \multirow[t]{2}{*}{$\mathrm{n}$} & \multicolumn{2}{|c|}{ Size $(\mathrm{cm})$} & \multirow[t]{2}{*}{$F$} & \multirow[t]{2}{*}{$\mathrm{p}$} \\
\hline & & Before & After & & \\
\hline Gurnards & 60 & $26.7 \pm 6.11$ & $24.4 \pm 4.9$ & 2.05 & 0.16 \\
\hline Dogfish & 60 & $55.2 \pm 7.1$ & $52.2 \pm 6.7$ & 3.03 & 0.09 \\
\hline Whiting & 80 & $20.8 \pm 2.5$ & $19.7 \pm 2.7$ & 2.98 & 0.09 \\
\hline
\end{tabular}


Table 3. Change in mean \pm SE prey width $(\mathrm{mm})$ in stomachs of gurnards Aspitrigla cuculus and Eutrigla gurnardus, dogfish Scyliorhinus canicula and whiting Merlangius merlangus collected before and after fishing. Comparisons were made using the Kruskal-Wallis non-parametric ANOVA $(H)$. Change in prey width:gape width ratio is also shown for each species

\begin{tabular}{|c|c|c|c|c|c|c|c|}
\hline \multirow{2}{*}{ Species } & \multirow[t]{2}{*}{$\mathrm{n}$} & \multicolumn{2}{|c|}{ Prey width } & \multirow[t]{2}{*}{$H$} & \multirow[t]{2}{*}{$\mathrm{p}$} & \multicolumn{2}{|c|}{ Prey width: gape width } \\
\hline & & Before & After & & & Before & After \\
\hline Gurnards & 132 & $5.78 \pm 1.00$ & $4.11 \pm 0.23$ & 0.03 & 0.85 & 0.23 & 0.16 \\
\hline Dogfish & 153 & $6.70 \pm 1.85$ & $6.14 \pm 0.38$ & 1.41 & 0.23 & 0.19 & 0.17 \\
\hline Whiting & 130 & $6.37 \pm 1.92$ & $4.43 \pm 1.78$ & 8.57 & 0.004 & 0.24 & 0.16 \\
\hline
\end{tabular}

$t=4.05, \mathrm{df}=22, \mathrm{p}<0.001)$. Fish marks were most concentrated closer to the trawl tracks, 80 occurred within $50 \mathrm{~m}$ of the tracks, 15 occurred from between 50 and $100 \mathrm{~m}$ and 16 from within 100 to $150 \mathrm{~m}$ of the trawl tracks (Fig. $3, \chi^{2}=36.1$, df $=2, p<0.001$ )

\section{Expt 3: April 1994}

\section{Dietary changes}

After trawling we found recently eaten remnants of animals that would not normally be available to fish such as whiting. As in April 1993, the gonads of the sea urchin Spatangus purpureus were found primarily in stomachs examined after fishing. Bivalve siphons and the feet of 2 species of infaunal bivalve, Ensis spp. and Laevocardium spp., were found in stomach contents after the area had been fished. Furthermore, the ripe gonads, mantles and adductor muscle of queen scallops Aequipecten opercularis and the scallop Pecten maximus occurred in stomach contents after the first tow (Table 5). Mysids and Ampelisca spinipes were the most common prey eaten by whiting both before and after fishing (Table 5). However, after fishing, whiting ate a significantly lower proportion of mysids ( $t$-test, $t=7.19$, df $=5, \mathrm{p}<0.001$ ) but increased the proportion of $A$. spinipes in their diet ( $t$-test, $t=5.35, \mathrm{df}=5, \mathrm{p}<0.013)$. The proportion of the other prey types did not vary significantly either

Table 4. Number of shoals of fish occurring either over the fished or the unfished areas per $2 \mathrm{~min}$ interval on the sidescan records which were obtained after tow $3(16: 00 \mathrm{~h})$ and tow $6(19: 00 \mathrm{~h})$. All comparisons between the mean numbers of shoals per 2 min were made using the $t$-test

\begin{tabular}{|lcccl|}
\hline & \multicolumn{2}{c}{ No. of shoals per 2 min } & $t$ & $p$ \\
& Unfished & Fished & & \\
\hline After tow 3 & $0.05 \pm 0.03$ & $0.58 \pm 0.23$ & 2.20 & 0.04 \\
After tow 6 & $6.41 \pm 1.50$ & $20.4 \pm 3.10$ & 4.05 & 0.001 \\
$t$ & 4.29 & 6.34 & & \\
$\mathrm{p}$ & 0.001 & 0.001 & & \\
\hline
\end{tabular}

before or after fishing. Prior to fishing $9 \%$ of the whiting examined had eaten $A$. spinipes, which increased to $30 \%$ after fishing.

\section{DISCUSSION}

\section{Diet composition prior to fishing}

Dogfish ate a broad range of prey types (Table 6) and sizes, which is similar to other dogfish species, such as Squalus acanthias, that maintain a varied diet throughout their life history (Jones \& Geen 1977, Hanchet 1991, Tanasichuk et al. 1991). The mean width of prey consumed by dogfish was much smaller than their maximum gape width (pw: $g w=0.19$ ). Despite the ability to consume large prey they continue to include a high percentage of small prey items (mostly Ampelisca spinipes, $31 \%$ ) in their diet (Table 3). In contrast gurnards ate a less diverse selection of prey (Table 6), mostly epifaunal crustaceans and fish, which is consistent with other studies (de Gee \& Kikkert 1993). As in other studies of whiting in this size range (Hislop et al. 1991), a wide range of prey was consumed, but the majority of the stomach contents were polychaetes and crustaceans. Most of the polychaetes consumed (e.g. Nereis sp., Phyllodoce sp.) are at times free swimming when they become accessible and visible to predators.

\section{Dietary changes after fishing}

Gurnards and whiting increased the mean number of prey eaten after the study areas were beam trawled. Consequently, stomach fullness and contents weight also increased significantly. However, dogfish did not increase their intake of prey or alter their diet after fishing. Gurnards altered the percentage composition of their diets after fishing and ate a proportionally greater number of Ampelisca spinipes than other prey. As A. spinipes is relatively small compared to most of the prey consumed, this may explain why no increase was detected in either stomach contents weight or fullness. In contrast, whiting ate a greater proportion of 


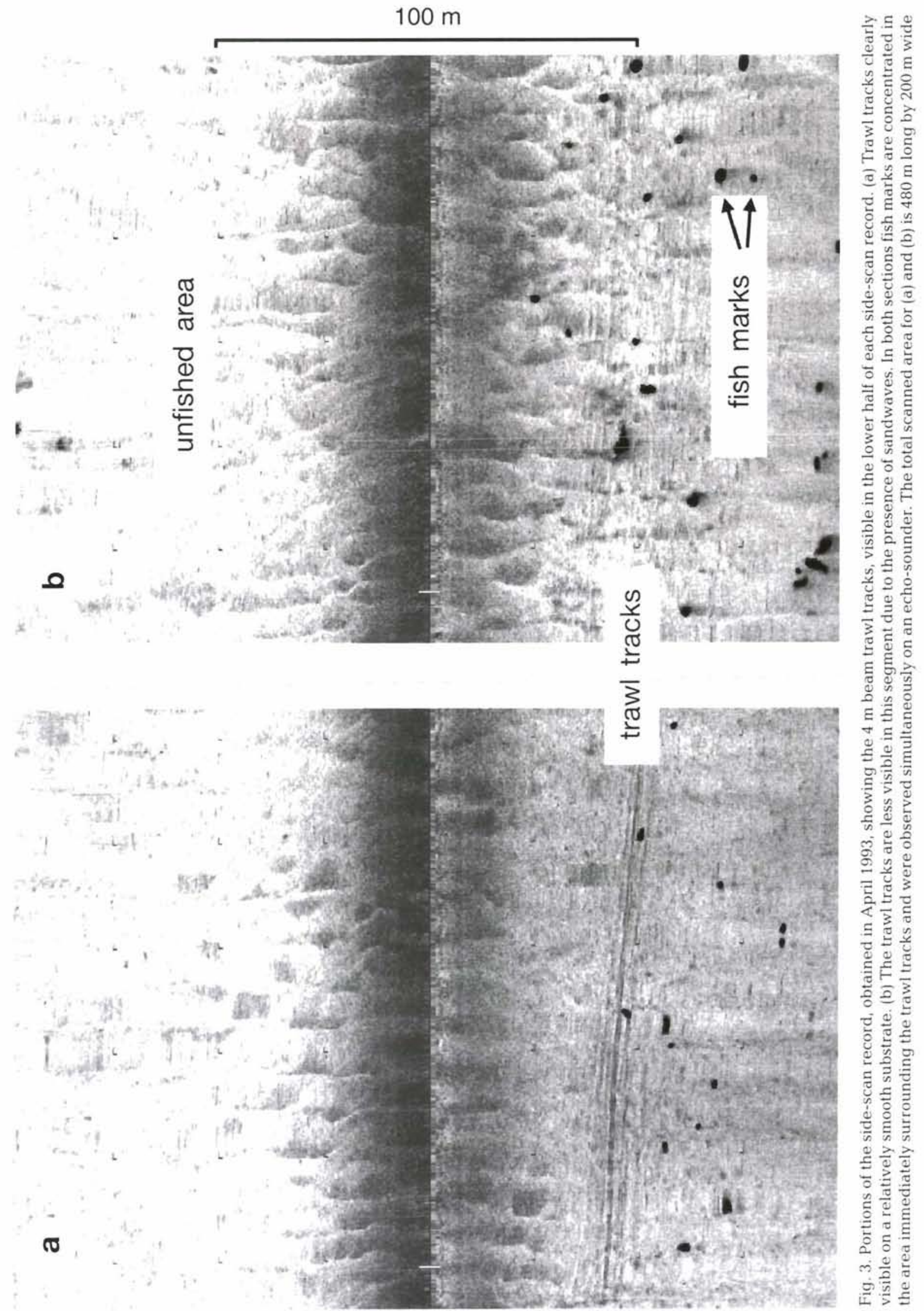


Table 5. Proportion of each prey type found in the total stomach contents of whiting Merlangius merlangus caught in tows 1 to 8 in April 1994. Mean of tows 1 to 4 and 5 to 8 given in parentheses. Significant differences only occurred for mysids and Ampelisca spp. Number of fish caught per tow as well as total number of prey examined is also given

\begin{tabular}{|c|c|c|c|c|c|c|c|c|c|c|}
\hline \multirow{2}{*}{ Tow number: } & \multirow[b]{2}{*}{1} & \multirow[b]{2}{*}{2} & \multirow[b]{2}{*}{3} & \multicolumn{6}{|c|}{ Proportion of stomach contents } & \\
\hline & & & & 4 & & 5 & 6 & 7 & 8 & \\
\hline Polychaetes & 0 & 0.04 & 0.02 & 0.06 & $(0.04)$ & 0.07 & 0.1 & 0.03 & 0.06 & $(0.07)$ \\
\hline Crustaceans & 0.01 & 0.05 & 0.14 & 0.04 & $(0.07)$ & 0.09 & 0.08 & 0.1 & 0.09 & $(0.09)$ \\
\hline Molluscs & 0.05 & 0.05 & 0.06 & 0.06 & $(0.06)$ & 0.12 & 0.02 & 0.08 & 0.09 & $(0.09)$ \\
\hline Fish & 0.15 & 0.02 & 0.02 & 0.04 & $(0.03)$ & 0.01 & 0 & 0 & 0.02 & $(0.01)$ \\
\hline Mysids & 0.65 & 0.72 & 0.63 & 0.71 & (0.69) & 0.3 & 0.35 & 0.42 & 0.46 & $(0.36)$ \\
\hline Ampelisca spp. & 0.05 & 0.1 & 0.08 & 0.08 & $(0.09)$ & 0.3 & 0.42 & 0.27 & 0.24 & $(0.32)$ \\
\hline Scallops & 0 & 0.01 & 0.02 & 0 & $(0.01)$ & 0.06 & 0 & 0.07 & 0 & (0.03) \\
\hline Spatangus & 0 & 0.01 & 0.03 & 0.02 & $(0.02)$ & 0.04 & 0.02 & 0.03 & 0.04 & $(0.03)$ \\
\hline No. of fish: & 21 & 90 & 43 & 38 & & 61 & 43 & 38 & 22 & \\
\hline No. of fish per $1000 \mathrm{~m}^{2}$ : & 8.8 & 33.8 & 14.3 & 12.1 & & 17.9 & 12.3 & 10.4 & 5.7 & \\
\hline Total no. of prey: & 20 & 143 & 63 & 52 & & 122 & 83 & 60 & 46 & \\
\hline
\end{tabular}

Table 6. List of animals collected from the stomach contents of gurnards Aspitrigla cuculus and Eutrigla gurnardus, dogfish Sycliorhinus canicula and whiting Merlangius merlangus, identified to the lowest possible taxonomic level

\begin{tabular}{|c|c|c|c|}
\hline & Gurnards & Dogfish & Whiting \\
\hline \multicolumn{4}{|l|}{ Polychaetes } \\
\hline Ampharete sp. & & & + \\
\hline Nephtys spp. & & + & + \\
\hline Phyllodocidae & & & + \\
\hline Nereidae & & & + \\
\hline Aphrodite aculeata & & + & \\
\hline \multicolumn{4}{|l|}{ Crustaceans } \\
\hline Ampelisca spinipes & + & + & + \\
\hline Liocarcinus depurator & + & + & \\
\hline Hyas areneus & & + & \\
\hline Macropodia spp. & + & & \\
\hline Eupagurus bernhardus & & + & \\
\hline Crangon spp. & + & + & + \\
\hline Pandalus spp. & + & + & + \\
\hline Upogebia deltaura & & + & \\
\hline Processa spp. & & & + \\
\hline Isopoda & + & & \\
\hline Mysidacea & & & + \\
\hline \multicolumn{4}{|l|}{ Molluscs } \\
\hline Buccinum undatum & & + & \\
\hline Natica alderi & + & & \\
\hline \multicolumn{4}{|l|}{ Aequipecten opercularis } \\
\hline \multicolumn{4}{|l|}{ Pecten maximus } \\
\hline (gonads, adductor muscle & & & + \\
\hline Ensis spp. (foot and siphons & & & + \\
\hline Laevocardium sp. (foot) & & & + \\
\hline \multicolumn{4}{|l|}{ Echinoderms } \\
\hline \multicolumn{4}{|l|}{ Spatangus purpureus } \\
\hline Paracucumaria hyndmani & & + & \\
\hline \multicolumn{4}{|l|}{ Pisces } \\
\hline Callionymus spp. & + & + & \\
\hline Ammodytidae & + & & \\
\hline
\end{tabular}

small prey after the area had been trawled (Table 3) which is probably associated with their increased intake of A. spinipes (Fig. 2, Table 5). In April 1994, whiting collected before fishing ate mostly mysids, however, after fishing they greatly increased their intake of A. spinipes and lowered the proportion of mysids eaten (Table 5).

As in other studies of demersal fish diets (Collie 1987. Dauvin 1988, Franz \& Tanacredi 1992), amphipods of the genus Ampelisca are clearly an important food source for gurnards, dogfish and whiting, especially when made more available as a result of beam trawling. A. spinipes inhabits a tube which protrudes above the surface of the sediment (P. G. Moore pers. comm.). These tubes are probably damaged as the beam trawl passes over them and the amphipods are exposed, making them vulnerable to predators. Although ampeliscids undertake nocturnal vertical migrations, these tend to occur between dusk and dawn (MacquartMoulin et al. 1987), which would not explain the observed increase in stomach contents, as all fishing occurred in daylight (Macquart-Moulin et al. 1987). A. spinipes appears to increase in importance as a food source when its availability is enhanced by the effects of trawling. We estimate that at our experimental site in the Irish Sea, with an average tow covering $15120 \mathrm{~m}^{2}$ of the sea bed and an average A. spinipes density of 140 ind. $\mathrm{m}^{-2}$ (Kaiser unpubl. data), the maximum number of $A$. spinipes that could become available as food would be approximately $4.2 \times 10^{6}$ per hour of fishing with this type of gear. These approximations only apply to our experimental areas and their associated community, but qualitatively similar situations may occur elsewhere.

It appears that after the passage of the trawl the occurrence of some prey items in the stomach contents of gurnards and whiting increases, e.g. Ampelisca 
spinipes. Clearly the latter are normally an important component of all the fish diets examined. Beam trawling may increase food availablity such that prey which are normally preferred (e.g. mysids) are displaced. This would indicate that $A$. spinipes are encountered more frequently by fish after an area has been beam trawled.

We observed that Liocarcinus depurator, Pandalus spp. and Crangon spp. either increased in the diet of gurnards and dogfish or were only eaten after trawling (Fig. 2). These crustaceans are mobile epibenthic scavengers (Wassenberg \& Hill 1987, Hall et al. 1990a, Hedqvist-Johnson \& Andre 1991), which locate carrion by following its scent in water currents (Sainte-Marie \& Hargrave 1987, Nickell \& Moore 1992). Presumably invertebrate scavengers aggregate over trawl tracks in response to the odour of animals damaged or killed by beam trawling, where, in turn, they will be vulnerable to predation by fish.

We do not attribute the observed dietary changes to diel variations in feeding activity, as all the fishing was carried out during daytime. Moreover, we found no evidence in the published literature to suggest that gurnards exhibit diurnal feeding patterns. However, Robb (1981) showed that the mean weight of whiting stomach contents increased steadily after dusk, which approximately coincided with the beginning of our final side-scan record (18:26 h, April 1993). The sudden appearance of fish marks on the side-scan sonar record also may be attributed to diurnal shoaling behaviour. The fish marks (presumed to be shoals of whiting) were viewed simultaneously on the side-scan sonar and on an echo sounder and were positioned within $1 \mathrm{~m}$ of the seabed. Furthermore, stomach contents indicated that whiting had been feeding on animals which had been recently damaged by the beam trawl, which has recently been confirmed by diver observations (unpubl. data). These animals included bivalves such as scallops and Laevocardium sp. which have strong shells, and sea urchins which are found buried in the sediment. Furthermore, these tissues had been eaten recently, as 1 scallop adductor muscle still contracted when touched (April 1994). These observations, coupled with the large proportion of fish marks observed directly over the trawl tracks strongly suggests that whiting were feeding on the trawled area.

\section{Conclusions}

Our study shows that gurnards and whiting aggregate over beam trawl tracks, either to feed on animals damaged by the beam trawl, or on other scavengers. However dogfish do not behave in a similar manner. Beam trawling has been cited as one possible factor that could cause large-scale changes in benthic communities (Pearson et al. 1985, Lindeboom 1990, Bergman \& Hup 1992). While some animals die as a result of the direct effects of trawling (e.g. benthos and bycatch) other animals are quick to capitalise on these by-products which could lead to large increases in the populations of certain species whose feeding mode was suited to this food source. The structure of fish populations is partly dependent on resource partitioning (Hall et al. 1990b), hence additional resources, such as those made available by trawling, may favour certain species that exhibit opportunistic feeding behaviour such as gurnards and whiting.

Acknowledgements. The authors thank Dave Raffaelli for constructive comments which helped to improve the manuscript. Reference to proprietary products in this paper should not be construed as an official endorsement of these products, nor is any criticism implied of similar products which have not been mentioned.

\section{LITERATURE CITED}

Arkley, K. (1991). Improved selectivity in beam trawls - an inventory of vessels and gear types engaged in beam trawling in the U.K. Seafish Industry report No. 1417, Hull, p. $1-7$

BEON (1991). Effects of beam trawl fishery on the bottom fauna in the North Sea. BEON rapport No. 13. Netherlands Institute for Sea Research, Texel, p. 1-85

Berghahn, R. (1990). On the potential impact of shrimping on trophic relationships in the Wadden Sea. In: Barnes, M., Gibson, R. N. (eds.) Trophic relationships in the marine ecosystem. Proc. 24th Eur. mar. biol. Symp. Aberdeen Univ. Press, Aberdeen, p. 130-140

Bergman, M. J. N., Hup, M. (1992). Direct effects of beamtrawling on macrofauna in a sandy sediment in the southern North Sea. ICES J. mar. Sci. 49:5-13

Bridger, J. P. (1970). Some effects of the passage of a trawl over a seabed. Comm. Meet. int. Coun. Explor. Sea C.M.ICES/B: 10

Bridger, J. P. (1972). Some observations on the penetration into the sea bed of tickler chains on a beam trawl. Comm. Meet. int. Coun. Explor. Sea C.M.-ICES/B: 7

Collie, J. S. (1987). Food consumption by yellowtail flounder in relation to production of its benthic prey. Mar. Ecol. Prog. Ser. 36: 205-213

Creutzberg, F., Duineveld, G. C. A., van Noort, G. J. (1987). The effect of different numbers of tickler chains on beamtrawl catches. ICES J. mar. Sci. 43: 159-168

Dauvin, J. C. (1988). The effects of macrobenthos on the feeding of demersal fishes living in the fine sand from western English Channel (in Morlaix Bay). Cah. Biol. mar. 29: $445-467$

de Gee, A., Kikkert, A. H. (1993). Analysis of the grey gurnard (Eutrigla gurnardus) samples collected during the 1991 international stomach sampling project. Comm. Meet. int. Coun. Explor. Sea C.M.-ICES/G: 14

Eleftheriou, A., Robertson, M. R. (1992). The effects of experimental scallop dredging on the fauna and physical environment of a shallow sandy community. Neth. J. Sea Res. 30: 289-299 
Franz, D. R., Tanacredi, J. T. (1992). Secondary production of the amphipod Ampelisca abdita Mills and its importance in the diet of juvenile winter flounder (Pleuronectes americanus) in Jamaica Bay, New York. Estuaries 15: 193-203

Furness, R. W. (1982). Competition between fisheries and seabird communities. Adv, mar. Biol. 20: 225-309

Furness, R. W., Hislop, J. R. G. (1981). Diets and feeding ecology of great skuas, Catharacta skua, during the breeding season in Shetland. J. Zool., Lond. 195: 1-23

Hall, S. J. (1994). Physical disturbance and marine benthic communities: life in unconsolidated sediments. Oceanogr. mar. Biol. A. Rev. 32: 179-239

Hall, S. J., Raffaelli, D., Robertson, M. R., Basford, D. J. (1990a). The role of the predatory crab, Liocarcinus depurator, in a marine food web. J. Anim. Ecol. 59: 421-439

Hall, S. J., Raffaelli, D., Basford, D. J., Robertson, M. R., Basford, D. J., Fryer, R. (1990b). The feeding relationships of the larger fish species in a Scottish sea loch. J. Fish. Biol. 37: 775-793

Hanchet, S. (1991). Diet of spiny dogfish, Squalus acnathias Linnaeus, on the east coast, South Island, New Zealand. J. Fish. Biol. 39: 313-323

Hedqvist-Johnson, K., Andre, C. (1991). The impact of the brown shrimp Crangon crangon L. on soft-bottom meiofauna: an experimental approach. Ophelia 34:41-49

Hislop, J. R. G., Robb, A. P., Bell, M. A., Armstrong, D. W. (1991). The diet and food consumption of whiting (Merlangius merlangius) in the north Sea. ICES J. mar. Sci. 48: 139-156

Jones, B. C., Geen, G. H. (1977). Food and feeding of spiny dogfish (Squalus acanthias) in British Columbia waters. J. Fish. Res. Bd Can. 34: 2067-2078

Kaiser, M. J., Rogers, S. 1., McCandless, D. (1994). Improving quantitative estimates of epibenthic communities using a modified $2 \mathrm{~m}$ beam trawl. Mar. Ecol. Prog. Ser. 106: $131-138$

Lindeboom, H. (1990). How trawlers are raking the North Sea to death. Daily Telegraph, March 16, 1990

Lyle, J. M. (1979). Feeding, utilization of food and growth in the lesser spotted dogfish, Syliorhinus canicula (L.), from Isle of Man waters. Ph.D. thesis, University of Liverpool

Macquart-Moulin, C., Bourdillon, A., Cubizolles, F., Passe-

This article was presented by R. N. Hughes (Senior Editorial Advisor), Bangor, UK laigue, F., Rosoanarivo, R. (1987). Un cas type de migration verticale 'retard' chez l'amphipode Ampelisca typica. J. Plankton Res. 9: 785-809

McCandless, D. T. (1992). Impact of bottom fishing on benthos. M.Sc. thesis, University of Wales, Bangor

Nickell, T. D., Moore, P. G. (1992). The behavioural ecology of epibenthic scavenging invertebrates in the Clyde Sea area: laboratory experiments on attractions to bait in static water. J. exp. mar. Biol. Ecol. 156: 217-224

Pearson, T. H., Josefson, A. B., Rosenberg, R. (1985). Petersen's benthic stations revisited. I. Is the Kattegatt becoming eutrophic? J. exp. mar. Biol. Ecol. 92: 157-206

Rijnsdorp, A. D., Groot, P., van Beek, F. A. (1991). The micro distribution of beam trawl effort in the southern North Sea. Comm. Meet. int. Coun. Explor. Sea C.M.ICES/G: 49

Robb, A. P. (1981). Observations on the food and diel feeding behaviour of pelagic 0-group gadoids in the northern North Sea. J. Fish. Biol. 18: 183-194

Rumohr, H., Krost, P. (1991). Experimental evidence of damage to benthos by bottom trawling with special reference to Arctica islandica. Meeresforsch. 33: 340-345

Sainte-Marie, B., Hargrave, B. T. (1987). Estimation of scavenger abundance and distance of attraction to bait. Mar. Biol. 94: 431-443

Tanasichuk, R. W., Ware, D. M., Shaw, W., McFarlane, G. A. (1991). Variations in diet, daily ration, and feeding periodicity of Pacific hake (Merluccius productus) and spiny dogfish (Squalus acanthias) off the lower west coast of Vancouver Island. Can. J. Fish. Aquat. Sci. 48: 2118-2128 van der Veer, H. W., Bergman, M. J. N., Beukema, J. J. (1985). Dredging activities in the Dutch Wadden Sea: effects on macrobenthic infauna. Neth. J. Sea Res. 19: 183-190

Van Dolah, R. F., Wendt, P. H., Livisen, M. V. (1991). A study of the effects of shrimp trawling on benthic communities in two South Carolina sounds. Fish. Res. 12: 139-157

Van Dolah, R. F., Wendt, P. H., Nicholson, N. (1987). Effects of a research trawl on a hard bottom assemblage of sponges and corals. Fish. Res. 5: 39-54

Wassenberg, T. J., Hill, B. J. (1987). Feeding by the sand crab, Portunus pelagicus, on material discarded from prawn trawlers in the Moreton Bay, Australia. Mar. Biol. 95: $387-393$

Manuscript first received: February 10, 1994

Revised version accepted: May 24, 1994 